\title{
Plasma progestagens as markers of feto-placental health
}

\author{
Jennifer C. Ousey', Abigail L. Fowden', P. D. Rossdale'2, L. Grainger ${ }^{3}$ and E. Houghton ${ }^{3}$ \\ 'University of Cambridge, Dept. of Physiology, Cambridge, England; ${ }^{2}$ Beaufort Cottage Stables, Newmarket, England; \\ ${ }^{3}$ Horseracing Forensic Laboratory, Fordham, England
}

\begin{abstract}
Summary
The pregnant mare produces many metabolites of progesterone (progestagens) which are present in high concentrations in maternal plasma in late gestation. Progesterone (P4) itself is undetectable during the second half of pregnancy. The role of these progestagens is not known but it is thought that they may regulate myometrial activity. The source of progestagens has been identified using mares which have had chronic catheters placed in fetal, umbilical and uterine blood vessels. The P4 precursor, pregnenolone (P5) is produced by the fetus and rapidly metabolised by the placenta/endometrium into P4 and other metabolites, notably $5 \alpha$-pregnane-3,20-dione (5 $\alpha$-DHP). These metabolites reenter the fetal circulation and are then further metabolised by the fetus and placenta and excreted into the maternal circulation. Because the enzymes necessary to metabolise progestagens are present in both the fetus and placenta/endometrium, an intact and healthy feto-placental unit is necessary for their production and, presumably, for maintenance of myometrial quiescence.

In healthy Thoroughbred (TB) and pony mares, total progestagen concentrations gradually increase during the last week(s) pre-partum and then decline $24 \mathrm{~h}$ before delivery. However, in mares which have placental damage and associated premature mammary development, total progestagen concentrations often are raised precociously and remain elevated until abortion or pre-term delivery. Many of their foals, although delivered before full term, demonstrate adrenocortical activity suggesting a relationship between adrenal development and maternal plasma progestagen concentrations. This relationship has been confirmed by studies in which fetuses or mares injected sequentially with adrenocorticotrophic hormone (ACTH), exhibit raised maternal progestagen concentrations. Because the fetus produces P5, possibly by the adrenal, metabolism of progestagens may be altered or enhanced if there is fetal stress and / or placental damage. In order to test this hypothesis, blood samples were collected from mares (7 TB, 1 pony) in late gestation (250-280 days) with clinical conditions such as placentitis, premature mammary development, vaginal discharge or colic. Specific progestagen profiles measured quantitatively using gas chromatography - mass spectrometry showed detectable levels of P4 and elevated metabolites ( $5 \alpha$-DHP, $\beta \beta$-diol, $20 \alpha-5 \mathrm{P}, \beta \alpha$-diol) compared with control mares at the same stage of pregnancy. Maternal P5 was not elevated. Progestagens were low in 2 mares which aborted within 72 h. These results suggest that the progestagen pathway may be blocked in the placenta whilst an alternative route for $5 \alpha$-DHP production may exist in the fetus. Low maternal P5 concentrations do not preclude enhanced fetal P5 production, but low progestagen concentrations overall were associated with fetal demise. A specific marker of feto-placental stress was not identified but different progestagen profiles were observed between healthy and compromised pregnant mares.
\end{abstract}

Keywords: $\quad$ progestagens, $5 \alpha$-pregnane,3,20-dione, mare, stress, abortion

\section{Plasmaprogestagen als Marker für eine gesunde fetoplazentale Einheit}

Die tragende Stute produziert zahlreiche Progesteron- (Progestagen-) Metaboliten, die während der späten Phase der Gravidität in hoher Konzentration im maternalen Plasma vorhanden sind. Progesteron (P4) selbst ist in der 2. Trächtigkeitshälfte nicht nachweisbar. Die Rolle dieser Progestagene ist noch nicht bekannt, aber man vermutet, dass sie die myometriale Aktivität regulieren. Die Herkunft der Progestagene wurde ermittelt, indem man bei Stuten über einen langen Zeitraum einen Katheter in die fetalen, umbilikalen und uterinen Blutgefäße gelegt hat. Der P4-Vorläufer, Pregnenolon (P5) wird von dem Fetus gebildet und schnell von der Plazenta/Endometrium in P4 und andere Metabolite, vor allem $5 \alpha$-pregnane-3,20-dione ( $5 \alpha$-DHP), verstoffwechselt. Diese Metaboliten kehren in den fetalen Kreislauf zurück und werden dort durch den Fetus und die Plazenta weiter verstoffwechselt und in den maternalen Kreislauf abgegeben. Weil die Enzyme, die notwendig sind, um die Progestagene zu metabolisieren, sowohl im Fetus als auch in der Plazenta/Endometrium vorhanden sind, ist für ihre Produktion und vermutlich für die Erhaltung der myometrialen Inaktivität, eine intakte und gesunde fetoplazentale Einheit notwendig.

Bei gesunden Vollblut- und Ponystuten steigt die Gesamtprogesteronkonzentration während der letzten Woche(n) vor der Geburt allmählich an und fällt dann 24 Stunden vor der Geburt ab. Dagegen steigt bei Stuten mit Schäden an der Plazenta und damit assoziierter vorzeitiger Entwicklung des Euters die Progesteronkonzentration häufig frühzeitig an und bleibt bis zum Abort oder der Frühgeburt erhöht. Obwohl diese Feten vor dem Geburtstermin geboren wurden, weisen viele eine adrenokortikale Aktivität auf, die auf eine Beziehung zwischen der Nebennierenentwicklung und der maternalen Plasma-Progesteron-Konzentration hindeutet. Dieser Zusammenhang wurde durch Studien bestätigt, in denen Feten oder Stuten mehrfach ACTH injiziert wurde und daraufhin eine erhöhte maternale Progesteronkonzentration festgestellt wurde. Da der Fetus P5, möglicherweise in der Nebenniere, produziert, kann der Metabolismus der Progestagene durch fetalen Stress und/ oder Plazentaschäden verändert oder gesteigert werden. Um diese Hypothese zu beweisen, wurden Blutproben von Stuten (7 Vollblut, 1 Pony) während der späten Trächtigkeit (250-280 Tage) entnommen. Diese wiesen als klinische Symptome Plazentitis, vorzeitige Euterentwicklung, vaginalen Ausfluss oder Kolik auf. Die spezifischen Progestagenprofile, die quantitativ mittels Gaschromatographie - Massenspektrometrie bestimmt wurden, zeigten messbare P4-Gehalte und einen erhöhten Gehalt an Metaboliten ( $5 \alpha$-DHP, $\beta \beta$-diol, $20 \alpha-5$, $\beta \alpha$-diol) verglichen mit den Kontrollstuten im gleichen Stadium der Trächtigkeit. Das maternale P5 war nicht erhöht. Die Progestagene waren bei 2 Stuten, die innerhalb von 72 Stunden abortiert haben, erniedrigt. Die Ergebnisse lassen vermuten, dass der Progesteronweg in der Plazenta blockiert sein könnte, während ein alternativer Weg für die 5 $\alpha$-DHP Produktion im Fetus existieren könnte. Niedrige maternale P5 Konzentrationen schließen eine erhöhte fetale P5 Produktion nicht aus, aber erniedrigte Progesteronkonzentrationen sind mit einem Absterben des Fetus assoziiert. Ein spezifischer Marker für fetoplazentalen Stress wurde nicht identifiziert, aber es wurden unterschiedliche Progestagenprofile bei den gesunden und den erkrankten trächtigen Stuten beobachtet.

Schlüsselwörter: Progestagene, 5 $\alpha$-pregnane,3,20-dione, Stute, Stress, Abort 


\section{Introduction}

Progesterone (P4) is involved in many aspects of female mammalian reproduction. During pregnancy, P4 plays a key role in maintaining uterine quiescence by suppressing myometrial contractions, inhibiting formation of uterine gap junctions and suppressing oxytocin receptor concentrations in the uterus (Cole and Garfield 1989; Soloff 1989). However in mares, particularly during the second half of pregnancy, the role of P4 is less clear and complicated by the presence of high circulating concentrations of progestagens, metabolites of P4 produced by the feto-placental unit. In this paper the role of P4 and progestagens will be reviewed in relation to maintenance of pregnancy and as markers of feto-placental health.

\section{Feto-placental metabolism of progesterone}

From about 100 days gestation, the equine fetus and placenta are actively involved in production and metabolism of P4 and progestagens as ovarian P4 production declines. Using pregnant pony mares with vascular catheters placed in the umbilical and uterine blood vessels and using highly specific gas chromatography - mass spectrometry (GC-MS) assay techniques, Holtan et al. (1991) identified at least 8 different progestagens, including P4, which circulate between the fetus and placenta/maternal endometrium during late (250-300 days) gestation (Figure 1). High concentrations (>400 ng/ml) of the P4 precursor pregnenolone (P5), produced by the fetus, are taken up from the umbilical artery and metabolised by the placenta and endometrium into P4 and $5 \alpha-\mathrm{DHP}$, respectively (Hamon et al. 1991). Some $5 \alpha-D H P$ is excreted unchanged into the maternal circulation but much is converted into other progestagens (Figure 1). Concentrations of $5 \alpha-\mathrm{DHP}$ which are at least twenty times higher in the umbilical vein than artery are metabolised by the fetus into $3 \beta 5 \mathrm{P}$ and $\beta \beta$-diol, probably in the liver, rather than the adrenals or gonads which do not possess the necessary enzymes (Chavatte et al. 1997). $5 \alpha$-DHP is also metabolised into $20 \alpha-5 P$ and $\beta \alpha-$ diol, via $3 \beta-5$, by the placenta and then excreted into the maternal circulation (Schutzer and Holtan

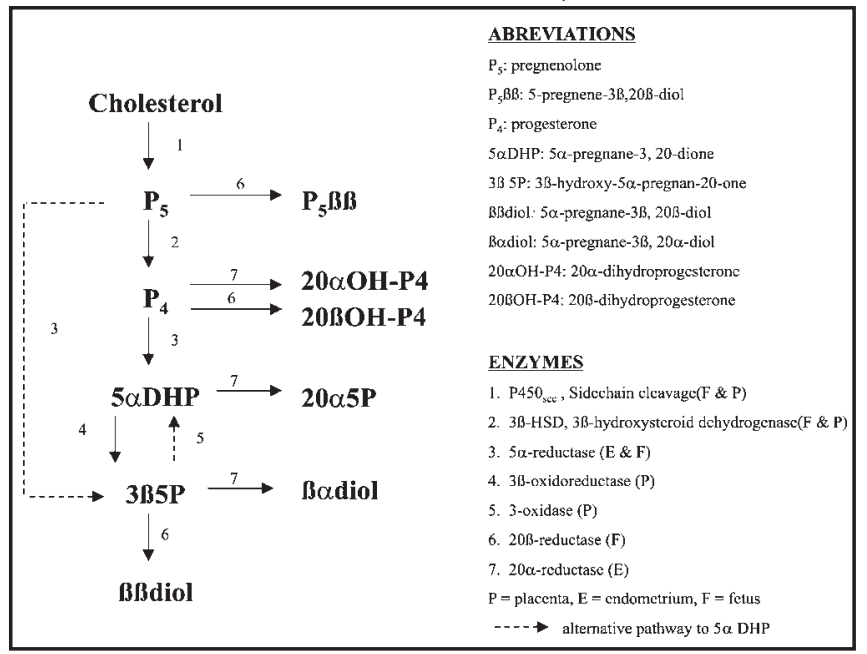

Fig. 1: Progestagen synthesis in the equine feto-placental unit

Progestagensynthese in der equinen fetoplazentalen Einheit
1996). Because P4 is metabolised within the placenta, little P4 is detected in the umbilical circulation $(<13 \mathrm{ng} / \mathrm{ml})$ and virtually none in maternal plasma $(<0.5 \mathrm{ng} / \mathrm{ml})$. In contrast, concentrations of $20 \alpha-5 \mathrm{P}, \beta \alpha-$ diol, $3 \beta-5 \mathrm{P}$ in maternal plasma range from 30 to $>1000 \mathrm{ng} / \mathrm{ml}$ in late gestation.

\section{Role of progestagens in late pregnancy}

A definitive biological role for progestagens has not been proven in the mare. After 150 days gestation, maternal ovariectomy does not cause abortion indicating the importance of fetoplacental progestagen production for pregnancy maintenance. Rising progestagen concentrations pre-partum are widely believed to prevent myometrial activity which increases towards term. However delivery can be induced with oxytocin or prostaglandin $F_{2 \alpha}$ despite the presence of high circulating progestagen concentrations (Jeffcott and Rossdale 1977). Because P4 is quantitatively insignificant in fetal and maternal circulation compared to other progestagens during late gestation, it has been postulated that a progestagen other than P4 may have biological activity in the mare, for example, $5 \alpha$ DHP. It competes more strongly than P4 for the uterine P4 receptor (Chavatte et al. 2000) and has an active role in the progestagen metabolic pathway (Figure 1). Therefore, it may prove to be of biological importance.

\section{Ontogenic changes in plasma progestagens}

Healthy mares

In healthy Thoroughbred (TB) mares, progestagen concentrations are relatively constant until about 300 days gestation when levels gradually increase, peaking 1 to 2 days before parturition (Figure 2 ); this rise is less pronounced, and more transient in pony mares (Rossdale et al. 1991). Specific progestagens which increase in maternal plasma pre-partum are $20 \alpha-5 \mathrm{P}$, $\alpha \alpha$-diol, $\beta \beta$-diol, $5 \alpha$-DHP and $3 \beta$-5P but P4 remains undetectable (Short 1959; Holtan et al. 1991). Recent evidence suggests that progestagens, including P5, also increase in the fetal circulation pre-partum (Fowden, Ousey and Houghton: unpublished observations). Utero-placental progestagen production may, therefore, rise in late gestation concurrent with an increase in fetal P5 output probably from the fetal adrenals which increase in weight during the last month of gestation. The decline in plasma progestagens over the last 1 to 2 days pre-partum occurs in parallel with a substantial surge in fetal plasma cortisol and maturation of the equine fetus (Silver and Fowden 1994).

\section{Abnormal mares}

In compromised mares, total progestagen profiles often deviate from the normal pattern. A decline in plasma progestagens has been reported for mares with colic, uterine torsion, equine herpes virus or babesiosis and is frequently associated with delivery of dead foals (van Niekerk and Morgenthal 1982; Ousey et al. 1987: Santschi et al. 1991). In contrast, placental or fetal abnormalities such as uterine infections, placental pathology, 
circulatory abnormalities, often are associated with increased maternal plasma progestagens at gestational ages when levels are usually low (Rossdale et al. 1991). This precocious increase
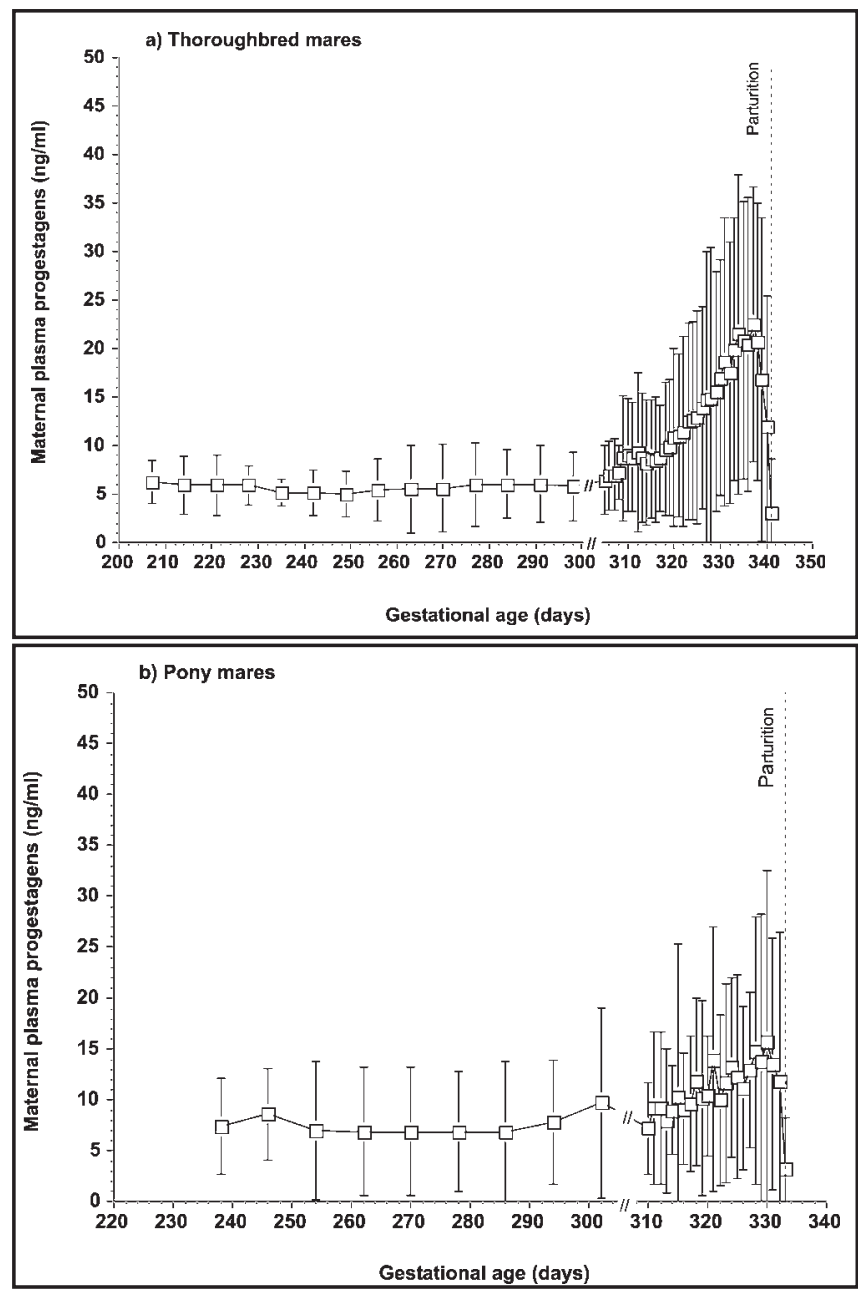

Fig. 2: Mean \pm 2 sd plasma progestagen concentrations measured by radioimmunoassay in a) TB $(n=25)$ and b) pony mares $(n=39)$, during the second half of pregnancy.

Mittelwert \pm 2sd Plasmaprogestagen-Konzentration, gemessen mit Hilfe eines Radioimmunassays

a) Vollblüter $(n=25)$ und b) Ponystuten ( $=39)$, während der zweiten Hälfte der Trächtigkeit.

in maternal progestagen levels is invariably associated with premature mammary development, expression of milk in the mare and delivery of live foals with some adrenocortical activity, even if born prematurely. Figure 3 shows a foal which was delivered at 277 days gestation from a TB mare with placental haemorrhage, raised plasma progestagens and premature mammary development. It weighed $21 \mathrm{~kg}$ and was viable with little neonatal care (Ousey and McGladdery 2000). Such clinical cases indicate a possible link between fetal adrenal activity and progestagen metabolism (see below). This relationship is also illustrated in pregnant mares eating fescue grass containing ergot alkaloids, in which gestation is prolonged; they have no pre-partum rise in plasma progestagens and the foals display hypoadrenocorticalism at delivery (Brendemeuhl et al. 1995). Feto-placental metabolism of progestagens appeared to be unaffected by maternal alkaloid ingestion because umbilical vein progestagen concentrations were no different in the foals at birth between control mares and those eating fescue grass. Different complications of pregnancy, therefore, lead to different progestagen profiles depending on the type and severity of the insult and on whether the insult is of maternal, fetal or placental origin.
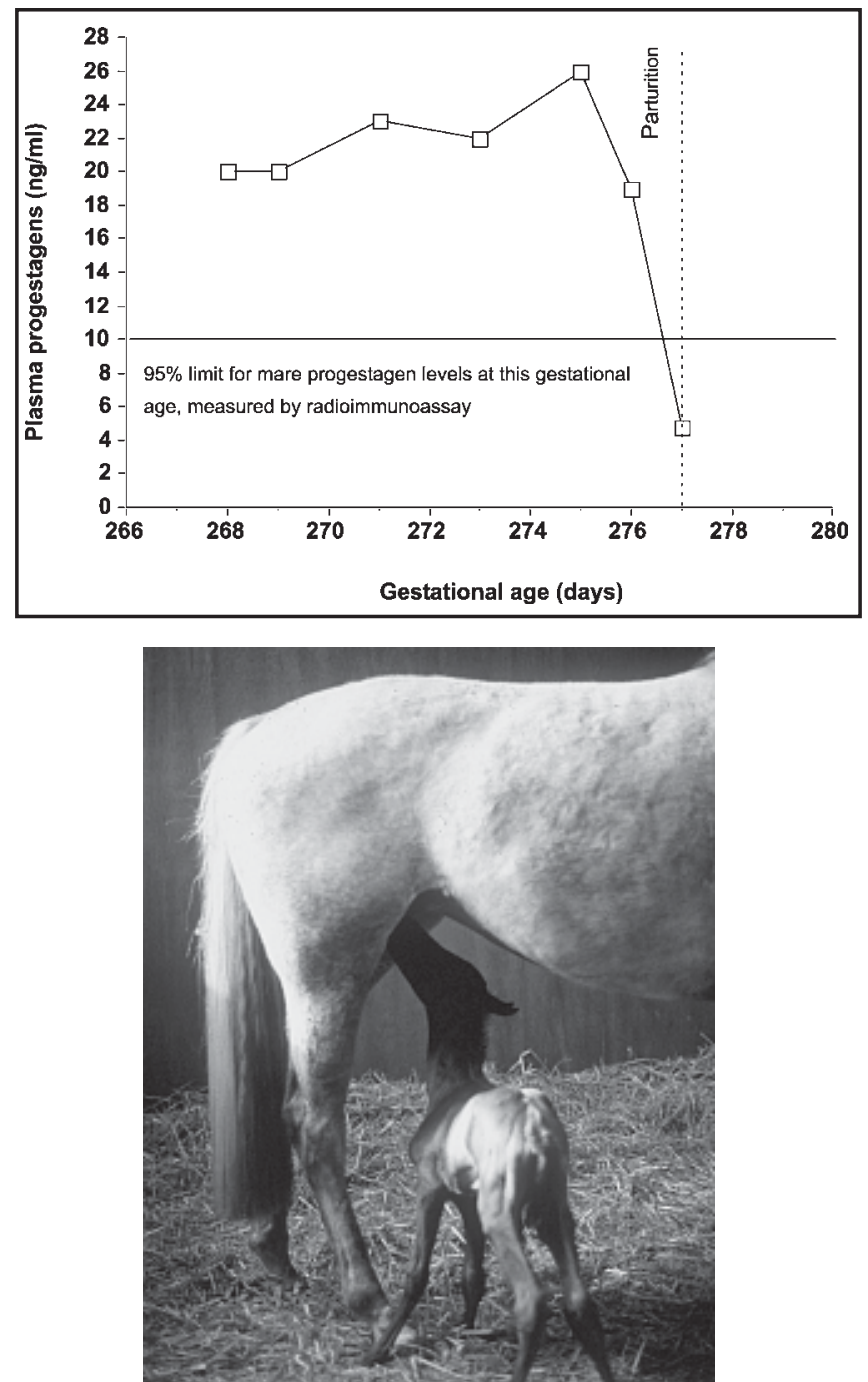

Fig. 3: (a) Plasma progestagens in a TB mare with placental haemorrhage and premature mammary development delivering a viable foal at 277 days gestation.

(b) TB foal born at 277 days gestation, body weight $21 \mathrm{~kg}$, with normal adrenocortical function.

(Photo by A. McGladdery).

(a) Plasmaprogestagene bei einer Vollblutstute mit plazentalen Blutungen und vorzeitiger Entwicklung des Euters, die ein lebensfähiges Fohlen am 277. Tag der Trächtigkeit geboren hat.

(b) Vollblutfohlen, am 277. Tag der Trächtigkeit geboren, Körpergewicht 21 kg, mit normaler adrenokortikaler Funktion.

\section{The relationship between maternal-feto-placental health and progestagens}

Because progestagens are produced and metabolised by the feto-placental unit, any clinical condition which affects fetal health or placental function is likely to disrupt production of progestagens. 
Fetal compromise

When the insult involves the fetus, it is likely to cause fetal stress. In sheep and other animals, fetal stress induced by, for example, hypoxaemia raises fetal cortisol concentrations (Challis et al. 1999). Normally, the fetal equine adrenal cannot produce cortisol from P4 because it lacks $17 \alpha-\mathrm{OH}$ activity, until close to, or after, parturition (Han et al. 1995). Similarly, exogenous ACTH does not stimulate a fetal cortisol response until close to term (Silver and Fowden 1994). Instead the fetal adrenal probably produces P5 which is taken up by the utero-placenta tissues. Fetal stress may increase adrenal activity and thereby lead to enhanced adrenal P5 and utero-placental progestagen production. Evidence for such a relationship is provided by both clinical (see above) and experimental observations. Maternal plasma progestagen concentrations ( $5 \alpha$-DHP, $\beta \alpha$-diol, $\beta \beta$-diol) increased significantly following intra-fetal injection with Depot $\mathrm{ACTH}, \mathrm{CRH}$ or betamethasone but not saline, and several foals were delivered prematurely with normal adrenocortical function (Rossdale et al. 1992; Ousey et al. 1998). The source of P5 within the fetus is not known but the fetal gonads, adrenals (and placenta) all contain the enzyme, P450 scc' $^{\prime}$ necessary to produce P5 from cholesterol (Figure 1; Han et al. 1995; Chavatte et al. 1997). Whatever the origin of $P 5$, there is strong evidence to suggest a relationship between fetal stress and increased circulating concentrations of progestagens.

\section{Placental compromise}

Placental damage, for example placentitis which can affect up to $80 \%$ of the surface area (Cottrill et al. 1991), would be expected to reduce progestagen production because of the key role the placenta plays in metabolism of P4 (Figure 1). Certainly in sheep, restriction of placental development causes a decline in circulating P4 despite a compensatory increase in placental blood flow (Falconer et al. 1985). However in many mares, placental damage causes an increase rather than decline in plasma progestagens. Rossdale et al. (1991) reported that of 24 TB mares with placental pathology, 20 had raised plasma progestagen concentrations, 16 of these detectable before 300 days gestation. Similarly, placental separation or ascending placentitis induced experimentally in pony mares caused a precocious increase in plasma progestagens (Rossdale et al. 1991; Reubel et al. 2000). The endocrine pathways associated with placental damage in the mare have not been investigated and may include hormones other than progestagens. In women, the placenta secretes $\mathrm{CRH}$ which can stimulate fetal adrenal cortisol production (Challis et al. 1999). If a similar endocrine pathway exists in the mare, placental $\mathrm{CRH}$ (or ACTH) may be secreted in response to a placental insult causing an increase in fetal adrenal P5 and enhanced progestagen metabolism by non-damaged areas of the placenta. Presumably if the placental damage is above a functional limit, then abortion or early delivery will occur.

\section{Maternal compromise}

When pregnant mares suffer from illness without apparent fetal or placental involvement, for example colic, the fetus may be protected, by the placental barrier, from maternal endocrine fluctuations. For example cortisol, released by the mare in response to stress, does not appear to cross the placenta in late gestation probably because of conversion to inactive cortisone by $11 \beta$-hydroxysteroid dehydrogenase in the placenta (Chavatte et al. 1995). Therefore progestagen metabolism is less likely to be affected by maternal disease unless this is prolonged or maternal cortisol levels are very high, resulting in altered fetoplacental steroid metabolism (Challis et al. 1999). Progestagen concentrations tend to remain constant unless the fetus or placenta becomes compromised when levels may rise or unless the mare aborts, when a declining profile is observed (see above). In mares carrying a dead fetus, progestagen levels are close to zero indicating the active role the healthy fetus plays in production of progestagens.

\section{Clinical significance of progestagen measurements from maternal plasma}

\section{Immunoassays}

Most P4 immunoassays measure not only P4 but also cross react with other progestagens, concentrations of which can exceed $1000 \mathrm{ng} / \mathrm{ml}$ in maternal plasma. Despite this, it is still possible to gain an assessment of feto-placental progestagen metabolism from maternal plasma, using immunoassays, providing profiles have been established for healthy mares and specific breeds. Several samples must be collected to determine whether concentrations deviate significantly from normal profiles and whether they are stable or changing. Using our radioimmunoassay which cross reacts 100\% with P4 and 6\% with $5 \mathrm{a}-\mathrm{DHP}, 95 \%$ (mean $+2 \mathrm{sd}$ ) of progestagen concentrations are $<10 \mathrm{ng} / \mathrm{ml}$ in healthy TB mares between about 200 to 300 days gestation; mares with levels outside this range before 300 days gestation are considered abnormal (Figure 3).

\section{GC-MS analysis}

Specific progestagens may provide better markers of fetoplacental health. This is currently being assessed using GCMS. Jugular venous samples $(n=31)$ were collected from 7 pregnant TB mares suffering from placental pathology (placentitis 5 , avillous placenta 1) or colic (1), and from a pony with fungal vaginal discharge. Five mares with placentitis and premature mammary development (250-280 days) had detectable levels of P4 and its immediate metabolites $20 \alpha-\mathrm{OH}-\mathrm{P} 4$ and $20 \beta$ $\mathrm{OH}-\mathrm{P} 4$ but P5 was not increased. $5 \alpha$-DHP, $\beta \beta$-diol, $20 \alpha-5 \mathrm{P}$, $\beta \alpha$-diol levels were higher than normal for this stage of pregnancy and $\beta \alpha$-diol and $\beta \beta$-diol levels were much higher compared with mares given intra-fetal ACTH/CRH (Rossdale et al. 1992). In the mare with an avillous placenta, P4 was detectable but all other progestagens were lower than control animals even at full term. Progestagens were very low in the mare with colic and the fetus was confirmed dead by ultrasound scan. The pony mare (unknown gestational age) also had low progestagen concentrations and the fetus was dead on delivery. These latter 2 cases indicate the importance of a functional feto-placental unit for progestagen production. In mares with 
placental abnormalities, it appears that a blockade may exist at the level of $5 \alpha$-reductase to increase P4 (Figure 1). However, the raised levels of $5 \alpha$-DHP and other metabolites tend to refute this suggestion. An alternative metabolic pathway for $5 \alpha$-DHP formation has been postulated via 3 $\beta-5 \mathrm{P}$ in the fetus (Schutzer and Holtan 1996; Figure 1) and, therefore, this may allow production of $5 \alpha$-DHP and other metabolites even when there is placental compromise. Alternatively fetal P5 and progestagen production may be increased as a result of fetal stress and the lack of change in maternal P5 concentrations may simply reflect the rapid metabolism of P5 by the placenta.

\section{Conclusions}

The role of progestagens in pregnant mares remains to be fully elucidated. The quantitative significance of P4 metabolites, rather than P4 itself, within the feto-placental circulation suggests that a metabolite, possibly $5 \alpha$-DHP, may have biological activity. The disruption of progestagen metabolism in compromised pregnancies has been clearly demonstrated; in general, declining patterns are associated with a poor prognosis whilst increasing levels are correlated with fetal stress and adrenocortical activity. Preliminary observations using GC-MS analyses have not linked specific progestagens to specific clinical problems. But these analyses have provided detailed quantitative information about feto-placental progestagen metabolism in healthy and compromised pregnant mares.

\section{Literature}

Brendemeuhl, J.P., Williams, M.A., Boosinger and Ruffin, D.C. (1995): Plasma progestagen, tri-iodothyronine, and cortisol concentrations in postdate gestation foals exposed in utero to the tall fescue endophyte Acremonium coenophialum. Biol. Reprod. Mono 1, 53-59.

Cole, W.C. and Garfield, R.E. (1989): Ultrastructure of the myometrium. In: Biology of the Uterus. Eds. R.M. Wynn \& W.P. Jollie. Second edition. Plenum Medical, London. 455-504.

Challis, J.R.G., Cox, D.B. and Sloboda, D.M. (1999): Regulation of corticosteroids in the fetus: control of birth and influence of adult disease. Semin. Neonatol. 4, 93-97.

Chavatte, P., Rossdale, P.D., and Tait, A.D. (1995): $11 \beta$-hydroxysteroid dehydrogenase (1 1 $\beta \mathrm{HSD}$ ) in equine placenta. Am. Assoc. Equine Pract., 41, 264-265.

Chavatte-Palmer. P., Duchamp, G., Palmer, E., Ousey, J.C., Rossdale, P.D. and Lombes, M. (2000): Progesterone, oestrogen and glucocorticoid receptors in the uterus and mammary glands of mares from mid- to late-gestation. J. Reprod. Fert., Suppl. 56, 661-672.

Chavatte, P., Holtan, D.W., Ousey, J.C. and Rossdale, P.D. (1997): Biosynthesis and possible biological role of progestagens during equine pregnancy and in the newborn foal. Equine vet. J. Suppl. 24, 89-95.

Cottrill, C.M., Jeffers-Lo, J., Ousey, J.C., McGladdery, A.J., Ricketts, S.W., Silver, M. and Rossdale, P.D. (1991): The placenta as a determinant of fetal well-being in normal and abnormal equine pregnancies. J. Reprod. Fert. Suppl. 44, 591-601.

Falconer, J., Owens, J.A., Allotta, E. and Robinson, J.S. (1985): Effect of restriction of placental growth on the concentrations of insulin, glucose, and placental lactogen in the plasma of the sheep. J. Endocrinol. 106, 7-11.

Holtan, D.W., Houghton, E., Silver, M., Fowden, Ousey, J., and Rossdale, P.D. (1991): Plasma progestagens in the mare, fetus and newborn foal. J. Reprod. Fert. Suppl. 44, 517-528.
Hamon, M., Clarke, S.W., Houghton, E., Fowden, A.L., Silver, M. Rossdale, P.D., Ousey, J.C. and Heap, R.B. (1991): Production of $5 \alpha-$ dihydroprogesterone during late pregnancy in the mare. J. Reprod. Fert. Suppl. 44, 529-535.

Han, X., Fowden, A.L., Silver, M., Holdstock, N., McGladdery, A.J., Ousey, J.C., Allen, W.R., Rossdale, P.D. and Challis, J.R.G. (1995): Immunohistochemical localisation of steroidogenic enzymes and phenylethanolamine-N-methyl-transferase (PMNT) in the adrenal gland of the fetal and newborn foal. Equine vet. J. 27, 140-146.

Jeffcott, L.B. and Rossdale, P.D. (1977): A critical review of current methods for induction of parturition in the mare. Equine vet. J., 9, 208-215.

Niekerk, C.H. van and Morgenthall, J.C. (1982): Fetal loss and the effect of stress on plasma progestagen levels in pregnant Thoroughbred mares. J. Reprod. Fert. Suppl. 32, 453-457.

Ousey, J.C., Rossdale, P.D., Cash, R.S.G. and Worthy. K. (1987): Plasma concentrations of progestagens. oestrone sulphate and prolactin in pregnant mares subjected to natural challenge with equid herpesvirus-1. J. Reprod. Fert. Suppl. 35, 519-528.

Ousey, J.C., Rossdale, P.D., Dudan, F.E. and Fowden, A.L. (1998): The effects of intrafetal ACTH administration on the outcome of pregnancy in the mare. Reprod. Fert. Dev., 10, 359-367.

Ousey, J.C. and McGladdery, A.J. (2000): Clinical diagnosis and treatment of clinical problems in the late pregnant mare. In Practice, 22, 200-207.

Reubel, H., Stawacki, R. and LeBlanc, M. (2000): Establishment of a model for ascending placentitis in the mare: clinical findings and progestin profiles. In: Havemeyer Foundation Workshop on Uterine Infection in Mares and Women: Comparative Aspects. Florida, USA. pp. 23 (Abstract).

Rossdale, P.D., Ousey, J.C., Cottrill, C.M., Chavatte, P., Allen, W.R. and McGladdery, A.J. (1991) Effects of placental pathology on maternal plasma progestagen and mammary secretion calcium concentrations and on neonatal adrenocortical function in the horse. J. Reprod. Fert. Suppl. 44, 579-590.

Rossdale, P.D., McGladdery, A.J., Ousey, J.C., Holdstock, N., Grainger, L. and Houghton, E. (1992): Increase in plasma progestagen concentrations in the mare after foetal injection with $\mathrm{CRH}, \mathrm{ACTH}$ or betamethasone in late gestation. Equine vet. J., 24, 341-350.

Santschi, E.M., LeBlanc, M.M. and Weston, P.G. (1991): Progestagen, oestrone sulphate and cortisol concentrations in pregnant mares during medical and surgical disease. J. Reprod. Fert., suppl. 44, 627-634.

Schutzer W.E. and Holtan, D.W. (1996): Steroid transformations in pregnant mares: metabolism of exogenous progestins and unusual metabolic activity in vivo and in vitro. Steroids, 61, 94-99.

Short, R.V. (1959): Progesterone in blood. IV. Progesterone in the blood of mares. J. Endocrinol., 15, 207-210.

Silver, M. and Fowden, A.L. (1994): Pre-partum adrenocortical maturation in the fetal foal: responses to $\mathrm{ACTH}_{1-24}$. J. Endocrinol. 142, 417-425.

Soloff, M.S. (1989): Endocrine control of parturition. In: Biology of the Uterus. Eds. R.M. Wynn \& W.P. Jollie. Second edition. Plenum Medical, London, 559-607.

\section{Acknowledgements}

This work was funded by the HBLB. The authors are grateful to veterinary and laboratory staff at Rossdale \& Partners Veterinary Surgeons, Newmarket, UK, for collection and assay of blood samples, and to Dr Ed Houghton and Lorraine Grainger (Horseracing Forensic Laboratories, Newmarket, UK) for GC-MS analyses.

Dr. Jennifer C. Ousey
University of Cambridge
Dept. of Physiology
Downing Street
Cambridge
CB2 3EG
UK
Tel.: ++44 1223333899
Fax: ++441223333840

